\title{
Pengungkapan Laporan Keuangan Sebagai Variabel Mediasi Pengaruh Kualitas Corporate Governance Terhadap Asimetri Informasi
}

\author{
Lailatul Amanah $^{1)}$, Nursiam ${ }^{2)}$, Suhesti Ningsih ${ }^{3)}$ \\ ${ }^{1)}$ Program Studi Akuntansi Sekolah Tinggi Ilmu Ekonomi Indonesia Surabaya \\ ${ }^{2}$ Fakultas Ekonomi dan Bisnis Universitas Muhammadiyah Surakarta \\ ${ }^{3)}$ Program Studi D3 Manajemen Pajak Institut Teknologi Bisnis AAS Surakarta \\ *Email korespondensi: lailatulamanah@stiesia.ac.id
}

\begin{abstract}
Abstarct
The application of good corporate governance is a fundamental need for companies and other institutions to succeed in the long term, good governance will force companies to conduct sufficient financial statement disclosures so as to reduce information asymmetry for users of financial statements. This study aims to examine whether quality of corporate governance influences information asymmetry through disclosure of financial statements. The object of this study is a non-financial category compannies that has obtained a score related to the implementation of corporate governance by IICG which was published in SWA magazine as the Most Trusted Conpany from 2012 to 2018. The sample selection process uses purposive sampling. The results of sample selection were obtained by 52 companies The data analysis technique in this study uses path analysis. The test of the direct effect of quality of corporate governance on information asymmetry shows that corporate governance quality has a positive effect on information asymmetry, while the test results of the indirect effect of corporate governance quality on information asymmetry through financial statement disclosure show that disclosure of financial statements is not a mediating variable on the effect of corporate governance quality on information asymmetry, this is caused because almost all sample companies make disclosures of financial statements in a relatively the same amount but the CG score results change in each year.
\end{abstract}

Keywords: corporate governance quality; financial statement disclosure; information asymmetry

Saran sitasi: Amanah, L., Nursiam., \& Ningsih, S. (2021). Pengungkapan Laporan Keuangan Sebagai Variabel Mediasi Pengaruh Kualitas Corporate Governance Terhadap Asimetri Informasi. Jurnal Akuntansi dan Pajak, 21 (2), 260-268. doi: http://dx.doi.org/10.29040/jap.v21i2.1512

DOI: http://dx.doi.org/10.29040/jap.v21i2.1512

\section{PENDAHULUAN}

Corporate governance merupakan kebutuhan perusahaan untuk bisa beroperasi secara etis, sehat, dan transparan. Kanagaretnam, et.al (2007) mendefinisikan corporate governance merupakan mekanisme yan, melakukan $\mathrm{g}$ diciptakan untuk menjamin bahwa manajemen bertindak untuk kepentingan shareholder sehingga mengurangi kemungkinan manajer bertindak untuk kepentingan dirinya sendiri pengungkapan informasi yang tidak benar atau pengungkapan informasi relevan namun dalam jumlah terbatas. Penerapan Good Corporate Governance (GCG) menuntut perusahaan untuk menyediakan informasi yang relevan mudah diakses dan dipahami oleh pemengku kepentingan, melakukan pengungkapan informasi yang cukup tidak hanya masalah yang disyaratkan oleh peraturan perundangundangan, tetapi juga juga hal yang penting untuk pengambilan keputusan oleh pemegang saham, kreditur, dan pemengku kepentingan lainnya. (KNKG, 2008)

Kebutuhan GCG timbul karena adanya masalah keagenan yang timbul karena keterpisasahan antara pemilik (Principal) dengan pengelola perusahaan (Agent). Pemilik dan pengelola sama-sama ingin memaksimumkan kepentingannya, pemilik menginginkan tingkat pengembalian investasi yang maksimum, begitu juga manajer menginginkan mendapatkan gaji dan bonus yang tinggi hal itu menimbulkan konflik keagenan. GCG juga dimaksudkan Untuk menjamin bahwa manajer bertindak untuk kepentingan terbaik shareholder, mengurangi kemungkinan manajer bertindak untuk kepentingan diri sendiri yang berarti akan menurunkan nilai perusahaan. 
Asimeri informasi muncul karena kepemilikan informasi yang berbeda antara investor atau kelompok investor, dan antara investor dan manajer. Asimetri informasi ini berakar dari teori keagenan yang menjelaskan problema yang timbul dari pemisahan pemilik dan manager sebagai agen. Manajer sebagai agen mengetahui informasi internal dan prospek perusahaan lebih banyak dari pada pemilik (principal), hal itu memicu manajer melakukan tindakan oportunis, misalnya pengambilan keputusan yang kurang efektif, yaitu melakukan selective disclosure, yaitu pengungkapan informasi yang memungkinkan memberikan keuntungan bagi manajer. Praktik ini mendorong ketidapercayaan investor terutama investor minoritas. (Barako et al. dalam Ndungo, 2014).

Sistem corporate governance optimal menjadi hal yang sangat penting, corporate governance yang optimal memberikan keyakinan bagi investor bahwa perusahaan dikelola secara efisien untuk menciptakan profitabilitas dan meningkatkan reputasi perusahaan (Glosten dan Milgrom dalam Shroff et al, 2013). Corporate governance optimal menghendaki perusahaan untuk menyediakan discolsure yang cukup yang tidak hanya meliputi informasi keuangan namun non keuangan yang meliputi isi, misi, sasaran usaha, dan strategi perusahaan, kondisi keuangan, susunan dan kompensasi pengurus, pemegang saham pengendali, kepemilikan saham oleh aggota dewan direksi dan komisaris, sistim manajemen risiko, sistem pengaasan dan pengendalian internal (KNKG, 2006)

Corporate governance yang optimal juga akan meningkatkan efektifitas anggota dewan, melalui pengawasan yang baik yang dilakukan oleh dewan komisaris, maka akan meningkatkan kualitas kerja direksi. Hal ini akan meningkatkan kualitas dan kuantitas informasi yang diungkapkan, hal ini akan mengurangi asimetri informasi.(Kanagaretnam, et al. 2007).

Penelitian terkait corporate governance dan asimetri informasi telah dilakukan oleh Ndungo (2014) pada pasar modal Naerobi. Corporate Governace diproksikan dengan kepemilikan saham oleh anggota dewan, independensi anggota dewan, dan dualitas $C E O$ yang dikaitkan dengan asimetri informasi. Hasil Penelitian menunjukkan bahwa kepemilikan saham oleh anggota dewan, dan independensi anggota dewan menurunkan asimetri informasi dan dualitas CEO meningkatkan asimeri informasi.
Penelitian lainnya dilakukan oleh Kanagaretnam, et al. (2007) yang menguji hubungan antara kualitas corporate governance dan asimetri informasi pada periode 3 bulan saat pengumuman laba. Corporate governance diproksi dengan independensi dewan, presentase komite audit independen, direksi yang berasal dari bisnis, jumlah anggota dewan, keberadaan komite nominasi independen, masa pension anggota dewan, jumlah pertemuan komite audit, jumlah pertemuan anggota dewan yang dikaitkan dengan asimetri informasi. Hasil penelitian menunjukkan terdapat hubungan negatif siknifikan antara asimetri informasi dengan independensi dewan, aktivitas dewan, persentasi saham oleh anggota dewan dengan variabel kontrol harga saham dan volatilitas harga. Hasil penelitian pada persamaan 2 yaitu terdapat hubungan positif siknifikan antara asimetri informasi (spread harga) dengan struktur dewan dan aktivitas dewan. Hasil yang sama juga dilakukan oleh Cormier et al. (2010) yang menemukan bahwa corporate governance mampu mengurangi asimetri informasi.

Penelitian ini berbeda dengan penelitian sebelumnya dalam hal pengukuran variabel corporate governance. Kalau penelitian sebelumnya corporate governance diukur dengan atribut dalam mekanisme corporate governance, maka penelitian ini menggunakan corporate governance score. Corporate governance score memberikan ukuran yang lebih baik, karena didasarkan pada penilaian pihak independen terhadap praktik corporate governance perusahaan. Perbedaan lain adalah dalam variabel mediasi yang digunakan. Dalam penelitian ini digunakan variabel mediasi pengungkapan laporan keuangan. Penggunaan variabel pengungkapan laporan keuangan sebagai variabel mediasi karena praktik corporate governance memaksa perusahaan untuk melaksanakan prinsip transparansi yang berarti mengungkapkan informasi secara transparan dan mudah diakses terkait informasi keuangan maupun non keuangan, adanya kelengkapan pengungkapan laporan keuangan akan mengurangi asimetri informasi baik antara manajer dengan investor maupun investor dengan investor lainnya (Shroff, 2013). Tujuan yang ingin dicapai dalam penelitian ini adalah untuk menguji apakah corporate governance berpengaruh terhadap asimetri informasi dan apakah pengungkapan laporan keuangan mampu memediasi. 


\section{Hipotesis}

Pengaruh Corporate Governance Terhadap Asimetri Informasi

Kebutuhan GCG timbul karena adanya masalah keagenan yang timbul karena keterpisasahan antara pemilik (Principal) dengan pengelola perusahaan (Agent). Pemilik dan pengelola sama-sama ingin memaksimumkan kepentingannya, pemilik menginginkan tingkat pengembalian investasi yang maksimum, begitu juga manajer menginginkan mendapatkan gaji dan bonus yang tinggi hal itu menimbulkan konflik keagenan.

GCG juga dimaksudkan Untuk menjamin bahwa manajer bertindak untuk kepentingan terbaik shareholder, mengurangi kemungkinan manajer bertindak untuk kepentingan diri sendiri yang berarti akan menurunkan value perusahaan. GCG juga dimaksudkan untuk mengurangi kemungkinan melakukan pengungkapan informasi yang tidak benar atau pengungkapan informasi relevan namun dalam jumlah terbatas, karena penerapan Good Corporate Governance (GCG) menuntut perusahaan untuk menyediakan informasi yang relevan mudah diakses dan dipahami oleh pemengku kepentingan, melakukan pengungkapan informasi yang cukup tidak hanya masalah yang disyaratkan oleh peraturan perundangundangan, tetapi juga juga hal yang penting untuk pengambilan keputusan oleh pemegang saham, kreditur, dan pemengku kepenting an lainnya. (KNKG, 2006)

Penerapan corporate governance yang optimal akan meningkatkan efektifitas anggota dewan, melalui pengawasan yang baik yang dilakukan oleh dewan komisaris, maka akan meningkatkan kualitas kerja direksi. Hal ini akan meningkatkan kualitas dan kuantitas informasi yang diungkapkan, dengan demikian akan mengurangi asimetri informasi.(Kanagaretnam et al. 2007).

H1: Corporate Governance berpengaruh negatif terhadap asimetri informasi

\section{Pengaruh Corporate Governance Terhadap Asimetri Informasi Melalui Pengungkapan Laporan Keuangan}

Asimetri informasi yang disebabkan karena adanya adverse selection menciptakan friksi perdagangan saham sehingga mendorong pada penurunan likuiditas (Bagehot dalam Shroff et al, 2013) penurunan likuiditas ini akan meningkatkan cost of capital perusahaan (Brennan dan Subramanyam dalam Shroff et al. (2013)
GCG optimal menghendaki perusahaan untuk menyediakan discolsure yang cukup yang tidak hanya meliputi informasi keuangan namun non keuangan yang meliputi visi, misi, sasaran usaha, dan strategi perusahaan, kondisi keuangan, susunan dan kompensasi pengurus, pemegang saham pengendali, kepemilikan saham oleh aggota dewan direksi dan komisaris, sistim manajemen risiko, sistem pengaasan dan pengendalian internal (KNKG, 2006)

Corporate governance yang optimal juga akan meningkatkan efektifitas anggota dewan, melalui pengawasan yang baik yang dilakukan oleh dewan komisaris, maka akan meningkatkan kualitas kerja direksi. Hal ini akan meningkatkan kualitas dan kuantitas informasi. (Kanagaretnam et al. 2007).

Kualitas pelaporan yang tinggi dapat membantu manajemen dan investor dalam pengambilan keputusan. Semakin tinggi kualitas pelaporan keuangan, maka informasi perusahaan semakin terefleksikan dengan baik dalam laporan keuangan. Kondisi ini dapat membantu pengambilan keputusan investasi menjadi lebih efisien karena semakin kecil asimetri informasi yang terjadi . Kualitas pelaporan keuangan yang tinggi dapat mengurangi asimetri informasi yang muncul dalam hubungan keagenan (Handayani, 2015) dan (Kanagaretnam, et al, 2007). Shroff et al (2013) menemukan bahwa perusahaan yang menyediakan disclosure siknifikan mengurangi asimetri informasi.

$\mathrm{H} 2$ : Corporate governance berpengaruh negatif terhadap asimetri informasi melalui pengungkapan laporan keuangan

\section{METODE PENELITIAN}

\section{Jenis Penelitian}

Jenis penelitian ini adalah penelitian korelasional antara dua variabel atau lebih yang bertujuan untuk melihat ada atau tidaknya korelasi antar variabel atau membuat prediksi berdasarkan korelasi antar variabel (Sugiyono, 2011). Penelitian ini merupakan tipe penelitin dengan karakteristik masalah berupa hubungan kuantitatif karena dilakukan dengan pengambilan sampel dari suatu populasi dan pengujian dengan alat statistik sebagai alat melakukan generalisasi. Pendekatan yang dipakai adalah komparatif dan korelasional.

\section{Populasi dan Sampel}

Populasi dalam penelitian ini adalah semua perusahaan yang terdaftar pada Bursa Efek Indonesia dan teknik pengambilan sampel yang digunakan 
adalah purposive sampling dengan kriteria sebagai berikut: a) Perusahaan non keuangan yang telah mendapatkan score terkait pelaksanaan corporate goverance oleh IICG (Indonesian Institute Corporate Governance) yang diterbitkan dalam majalah SWA dan b) Menerbitkan laporan keuangan tahun 20122018.

\section{Metode Pengumpulan Data}

Data penelitian ini adalah data sekunder. Kualitas corporate governance diukur dengan Corporate Governance Score. Data Corporate Governance Score diperoleh dari Corporate Governance Perceptio Index (CGPI) yang diterbitkan oleh majalah SWA, dan data pengungkapan laporan keuangan dan harga saham diambil dari Annual Report perusahaan yang diambil Galeri Investasi STIESIA Surabaya.

\section{Definisi Variabel Operasional Kualitas Corporate Governance}

Corporate governance adalah suatu struktur yang mengatur pola hubungan harmonis tentang peran dewankomisaris,direksi, pemegang saham dan para stakeholder, kualitas corporate governance diukur dengan Score Corporate governance yang merupakan ukuran yang menunjukkan seberapa baik tata kelola perusahaan dari corporate governance perception index (CGPI) yang dikeluarkan oleh Indonesian Institute Corporate Governance (IICD).

\section{Pengungkapan Laporan Keuangan}

Dalam penelitian ini, pengukuran ungkapan sukarela dilakukan berdasarkan pengembangan daftar item ungkapan sukarela yang mengacu pada penelitian sebelumnya yang pernah dilakukan di Indonesia, yaitu Suripto (1999), Marwata (2000) yaitu luas pengungkapan relatif setiap perusahaan diukur dengan indeks yang merupakan rasio total skor yang diberikan kepada sebuah perusahaan dengan skor yang diharapkan dapat diperoleh oleh perusahaan tersebut. Perusahaan diberi skor 1 jika mengungkapkan item informasi dalam instrumen dan diberi skor 0 jika tidak mengungkapkan.Butir pengungkapan laporan keuangan yang diukur meliputi yang bersifat wajib (mandatory) maupun sukarela (voluntary). Berdasarkan Surat Keputusan Bapepam No.06/PM/2000 luas pengungkapan wajib diukur dengan menggunakan 79 item pengungkapan, sedangkan luas pengungkapan sukarela diukur berdasarkan daftar item pengungkapan sukarela dari laporan tahunan yang dikembangkan berdasarkan literatur (Susanto, Choi dan Mueller, Meek et al.; dalam Suripto, 1999).
Dalam melakukan penghitungan angka indeks, peneliti menggunakan instrumen yang digunakan Wallace et al. (1987). Instrumen ini memberi angka tambahan pada setiap pengungkapan butir yang material. Semakin banyak butir yang diungkap oleh perusahaan, semakin banyak pula angka indeks yang diperoleh perusahaan tersebut. Perusahaan dengan angka indeks yang lebih tinggi menunjukan bahwa perusahaan tersebut melakukan praktek pengungkapan secara lebih komprehensif relatif dibandingkan perusahaan lain. Angka indeks maksimum dalam instrumen ini adalah satu. Perusahaan yang memiliki angka indeks satu menunjukan bahwa perusahan tersebut telah melakukan pengungkapan laporan keuangan secara penuh. Perhitungan untuk mencari angka indeks ditentukan dengan formulasi sebagai berikut :

$$
\frac{n}{K}
$$

Dimana :

$\mathrm{n}=$ jumlah butir pengungkapan yang dipenuhi

$\mathrm{K}=$ jumlah semua butir yang mungkin dipenuhi

\section{Asimetri Informasi}

Proksi yang digunakan untuk mengukur asimetri Informasi dengan menggunakan bid-ask spread. Bidask spread yang digunakan merupakan spread pasar, yaitu selisih antara harga jual tertinggi (highest ask) dengan harga penawaran/beli terendah (lowest bid) untuk saham tertentu. Penelitian ini mengukur asimetri informasi dengan menggunakan relative bidask spread yang dioperasionalkan sebagai berikut:

SPREADi, $\mathrm{t}=($ aski, $\mathrm{t}-$ bidi, $\mathrm{t}) /\{($ aski, $\mathrm{t}+$ bidi, $\mathrm{t}) / 2\}$

Keterangan:

aski,t: harga ask tertinggi saham perusahaan i yang terjadi pada hari $\mathrm{t}$

bidi,t: harga bid terendah saham perusahaan i yang terjadi pada hari $\mathrm{t}$

\section{Metode Pengumpulan Data}

Data penelitian ini adalah data sekundair, yaitu data corporate governace score diambil dari majalah SWA yang bekerja sama dengan Indonesian Institute Corporate Directorship. Data lain, yaitu harga saham dan pengungkapan laporan keuangan diperoleh dari galeri ivestasi Stiesia Surabaya.

\section{Teknik Analisis Data}

\section{Uji Statistik Deskriptif}

Statistik deskriptif merupakan alat, teknik, atau prosedur yang digunakan untuk menggambarkan atau mendeskripsikan kumpulan data atau hasil pengamatan yang telah dilakukan. Statistik deskriptif 


\section{Jurnal Akuntansi dan Pajak, 21 (02), 2021, 264}

ini merupakan metode-metode yang berkaitan dengan pengumpulan, peringkasan, dan penyajian suatu data sehingga memberikan informasi yang berguna dan juga menatanya ke dalam bentuk yang siap untuk dianalisis. Dengan kata lain, statistik deskriptif ini merupakan fase yang membicarakan mengenai penjabaran dan penggambaran termasuk penyajian data.

\section{Analisis Jalur (Path Analysisis)}

Teknik analisis yang digunakan dalam penelitian ini adalah path analysis (Analisis Jalur). Analisis jalur digunakan untuk menganalisis pola hubungan antar variabel dengan tujuan untuk mengetahui pengaruh langsung dari seperangkat variabel bebas (eksogen) terhadap variabel terikat (endogen). Analisis jalur juga bermanfaat sebagai expalanasi terhadap fenomeafenomena yang dipelajari atau permasalahan yang diteliti. Asumsi yang mendasari analisis ini adalah: 1) Hubungan antar variabel linier. 2) Hanya sistem aliran kausal ke satu arah artinya tidak ada arah kausalitas terbalik. 3) Variabel terikat (endogen) minimal dalam skala ukur interval dan rasio. 4) Menggunakan sampel probability sampling (Riduwan dan Kuncoro, 2013).

Fungsi dari penelitian ini adalah untuk melakukan pendugaan perubahan variabel asimetri informasi sebagai variabel terikat apabila terjadi perubahan variabel corporate governance, yang dimediasi oleh variable pengungkapan laporan keuangan. Dengan demikian model regresinya dapat dinyatakan sebagai berikut:

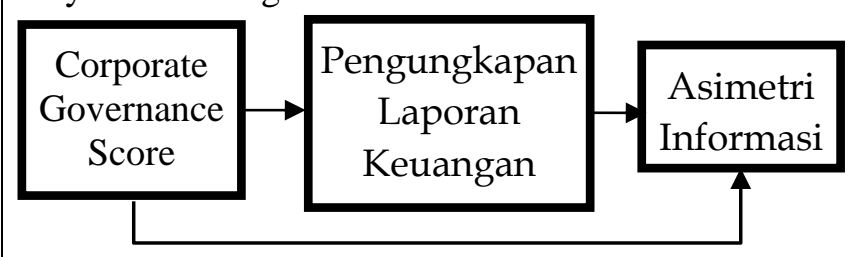

Gambar 1

\section{Model Analisis Jalur}

Model Regresi dapat dirumuskan sebagai berikut:

a. Pengujian langsung

$\mathrm{AI}=\alpha+\beta \mathrm{CG}$

b. Pengujian tidak langsung

$\mathrm{AI}=\alpha+\beta$ PLK

$\mathrm{AI}=\alpha+\beta 1 \mathrm{GCG}+\beta 2 \mathrm{PLK}$

\section{Uji Goodness of fit}

Pengujian ini utuk mengetahui apakah model regresi yang dibentuk fit, artinya apakah kualitas corporate governance, dan pengungkapan laporan keuangan sesuai sebagai variabel penjelas asimetri informasi. Kriteria untuk melihat kesesuaian model yaitu dengan melihat hasil pengujian uji F. Jika tingkat siknfikansi $\mathrm{F}<0,05$, maka corprate governance dan pengungkapan laporan keuangan sesuai sebagai variabelpenjelas asimetri informasi.

\section{Pengujian Hipotesis}

Pengujian hipotesis 1, yaitu menguji pengaruh langsung variabel dependen yaitu kualitas corporate governance $(\mathrm{CG})$ terhadap variabel independen yaitu asimetri informasi. Sebagaimana tampak pada model 1 , untuk melihat pengaruh tersebut dengan melihat tingkat siknifikansi t, jika tingkat siknifikansi $t<0,05$, berarti terdapat pengaruh langsung $\mathrm{CG}$ terhadap asimetri informasi.

Pengujian hipotesis 2, yaitu menguji pengaruh tidak langsung kualitas CG terhadap asimetri informasi melalui pengungkapan laporan keuangan. Pada pengujian hipotesis 2 dilakukan dalam dua tahap sebagaimana tampak pada model 2 dan 3. Pada pengujian tahap 2 (model 2) untuk menguji variabel kualitas pengungkapan laporan keuangan terhadap asimetri informasi dan pengujian tahap III (model 3) digunakan untuk mengetahui apakah kualitas CG dan Pengungkapan laporan keuangan berpengaruh terhadap asimetri informasi. Pengungkapan laporan keuangan dikatakan mampu memediasi pengaruh CG terhadap asimetri informasi jika hasil uji tahap II dan tahap III memiliki tingkat siknifikansi <0,05 (Latan dan Temalagi, 2013.

\section{HASIL ANALISIS DAN PEMBAHASAN}

\subsection{Hasil Penelitian}

Penerapan corporate goverance yang baik akan mendorong perusahaan melakukan pengungkapan laporan keuangan yang cukup yang bisa digunakan oleh investor, kreditor serta pihak lain untuk pengambilan keputusan. Pengungkapan laporan keuangan yang cukup akan meminimalisir adanya ketimpangan informasi antara manajemen dengan pihak luar yang akan menggunakannya untuk pengambilan keputusan. Penelitian ini bertujuan untuk menguji pengaruh kualitas corporate governance terhadap asimetri informasi dan menguji apakah pengungkapan laporan keuangan merupakan variabel mediasi pengaruh kualitas CG terhadap asimetri informasi. Sampel penelitian adalah perusahaan yang terscore nilai GCG oleh CGPI yang termuat di majalah SWA. Analisis data menggunakan regresi linier berganda. Adapun hasil penelitian dapat disimpulkan sebagai berikut: 


\section{Hasil Uji Statistik Deskriptif}

Berdasarkan hasil olah statistik atas data penelitian dapat ditemukan hal-hal penting terkait penyebaran data sebagai berikut:

Tabel 1

\section{Descriptive Statistics}

\begin{tabular}{|c|c|c|c|c|c|}
\hline & $\overline{\mathrm{N}}$ & $\begin{array}{c}\text { Minim } \\
\text { um }\end{array}$ & $\begin{array}{l}\text { Maxi } \\
\text { mum }\end{array}$ & $\overline{\text { Mean }}$ & $\begin{array}{c}\text { Std. } \\
\text { Deviation }\end{array}$ \\
\hline Ln CGScore & 51 & 61,072 & 91,18 & 82,84 & 4,997 \\
\hline Ln ASM & 51 & 0,001 & 0,45 & 0,318 & 0,0935 \\
\hline Ln Unkp & 51 & 0,603 & 0,90 & 0,7589 & 0,0745 \\
\hline $\begin{array}{l}\text { Valid N } \\
\text { (listwise) }\end{array}$ & 51 & & & & \\
\hline
\end{tabular}

Sumber: Score CG dan Laporan Tahunan

Dari tabel 1 dapat dilihat variabel corporate governance memiliki nilai minimum 61,72 yaitu Bakri Telecom dan nilai maksimum 91,18 yaitu Telcom Indonesia dengan standar deviasi 4,997 dan rata-rata 82,84 . Untuk variabel asimeri informasi nilai minimum 0,001, yaitu United Tractor dan nilai maksimum 0,45 yaitu Bakri \&Brothers dan standar deviasi 0,0935 dan nilai rata-rata 0,318 . Pengungkapan laporan keuangan memiliki nilai minimum 0.603, yaitu Bukit Asam dan nilai maksimum 0,90 PT Garuda Indonesia dengan nilai rata-rata 0,0589 dan standar deviasi 0,0745.

Pengujian Pengaruh Langsung (Efek Utama) Kualitas CG Terhadap Asimetri Informasi

Pengujian ini utuk mengetahui apakah model regresi yang dibentuk fit, dalam arti apakah variabel Kualitas CG sesuai sebagai variabel penjelas dari perubahan asimetri informasi. Hasil Uji kesesuaian model (Uji F) tampak pada tabel 5. Dari tabel 5 bisa dilihat hasil uji $\mathrm{F}$ pada efek utama, yaitu pengaruh GCG terhadap asimetri informasi mendapatkan nilai F 32,197 dengan tingkat signifikansi sebesar 0,00 yang berarti bahwa Kualitas CG sesuai sebagai variabel penjelas asimetri informasi.

Tabel 2

Hasil Uji Kesesuaian Model 1

\begin{tabular}{|c|c|c|c|c|}
\hline Model & $\begin{array}{l}\text { Sum of Df } \\
\text { Squares }\end{array}$ & $\begin{array}{c}\text { Mean } \\
\text { Square }\end{array}$ & $\mathrm{F}$ & Sig. \\
\hline Regression & $35,619 \quad 1$ & 35,619 & 32,197 & $.0,00^{\mathrm{b}}$ \\
\hline 1 Residual & $54,208 \quad 49$ & 1,106 & & \\
\hline Total & $89,827 \quad 50$ & & & \\
\hline
\end{tabular}

a. Dependent Variable: Asimetri Info

b. Predictors: (Constant), CGScore

Sumber: Score CG dan Laporan Tahunan
Pengujian efek utama untuk melihat pengaruh langsung variabel GCG terhadap asimetri informasi. Hasil uji pengaruh langsung GCG terhadap asimetri informasi tampak pada tabel 6 .

Tabel 3

\section{Hasil Uji Hipotesis 1}

Coefficients $^{\mathrm{a}}$

\begin{tabular}{cccccc}
\hline Model & \multicolumn{2}{c}{$\begin{array}{c}\text { Unstandardized } \\
\text { Coefficients }\end{array}$} & $\begin{array}{c}\text { Standardized } \\
\text { Coefficients }\end{array}$ & t & Sig. \\
\cline { 2 - 6 } & $\mathrm{B}$ & Std. & Beta & & \\
& & Error & & & \\
\hline (Constant) & 55,672 & 10,691 & & 5,207 & 0,000 \\
CG Score & $-13,739$ & 2,421 & $-0,600$ & $-5,647$ & 0,000 \\
\hline
\end{tabular}

a. Dependent Variable: Asimetri Informasi

Sumber: Score CG dan Laporan Tahunan

Dari tabel 6 dijelaskan bahwa hasil uji pengaruh langsung menunjukkan hasil signifikan dengan tingkat signifikansi 0,00 dan koefisien -13, 739 yang berarti hipotesis 1 diterima.

Pengujian Pengaruh Tidak Langsung (Pengaruh Kualitas CG terhadap asimetri informasi melalui pengungkapan laporan keuangan)

Uji Kesesuaia Model (Uji F)

Hasil uji kesesuaian model (Uji F) variabel CG Score dan pengugkapan laporan keuangan dan variabel asimetri informasi menunjukkan hasil berikut seperti tampak pada tabel 7

Tabel 4

Hasil Uji Kesesuaian Model 2

ANOVA $^{a}$

\begin{tabular}{|c|c|c|c|c|c|}
\hline Model & $\begin{array}{l}\text { Sum of } \\
\text { Squares }\end{array}$ & $\overline{\mathrm{Df}}$ & $\begin{array}{l}\text { Mean } \\
\text { Square }\end{array}$ & $F$ & Sig. \\
\hline Regression & 36,481 & 2 & 18,241 & 16,413 &, $000^{\mathrm{b}}$ \\
\hline Residual & 53,346 & 48 & 1,111 & & \\
\hline Total & 89,827 & 50 & & & \\
\hline
\end{tabular}

a. Dependent Variable: LN_ASSIF

b. Predictors: (Constant), LN_PENGLK,

LN_CGScore

Pada tabel tersebut tampak bahwa model regresi fit, dimana tingkat signifikansi F sebesar 0,000

\section{Uji Hipotesis Model 2}

Hasil Uji regresi pengaruh langsung CGScore dan pengungkapan laporan keuangan terhadap asimetri informasi menujukkan hasil sebagai berikut:

Tabel 7 menunjukkan variabel CG score berpengaruh negatif signifikan dengan tingkat signifikansi 0,000 dan koefisien -13,839, sedangkan variabel pengungkapan laporan keuangan menunjukkan hasil yang tidak signifikan yaitu tingkat signifikansi 0,383 . 
Tabel 5

Hasil Uji Hipotesis Pengaruh Tidak Langsung Coefficients $^{\mathrm{a}}$

\begin{tabular}{lrrrrr}
\hline \multicolumn{7}{c}{ Unstandardized } & $\begin{array}{l}\text { Standardized } \\
\text { Coefficients }\end{array}$ & Coefficients & Sig. \\
& B & Std. & Beta & & \\
& & Error & & & \\
\hline (Constant) & 55,481 & 10,755 & & 5,252 & 0,000 \\
CGscore & $-13,839$ & 2,429 & $-0,634$ & $-5,696$ & 0,000 \\
UNKP & 1,305 & 1,482 & 0,098 & 0,881 & 0,383 \\
\hline
\end{tabular}

a. Dependent Variable: Asimetri Infomasi

Sumber: Score CG dan Laporan Tahunan

Untuk melihat apakah pengungkapan laporan keuangan merupakan variabel mediasi pengaruh Kualitas CG terhadap asimetri informasi, berikut ini hasil olah regresi yang menguji kemampuan pengungkapan laporan keuangan sebagai variabel mediasi pengaruh Kualitas CG terhadap asimetri informasi. Tabel 6 meringkas hasil uji variabel pengugkapan sebagai variabel mediasi. Dari tabel tersebut tampak tingkat signifikansi Kualitas CG terhadap pengungkapan laporan keuangan 0,744 dengan koefisien 0,077. Dengan demikian bisa disimpulkan bahwa pengungkapan laporan keuangan bukan variabel mediasi pengaruh Kualitas CG terhadap asimetri informasi.

$$
\text { Tabel } 6
$$

Hasil Uji Variabel Mediasi

Coefficients $^{\text {a }}$

\begin{tabular}{lcccccc}
\hline \multirow{2}{*}{ Model } & \multicolumn{2}{c}{$\begin{array}{c}\text { Unstandardized } \\
\text { Coefficients }\end{array}$} & $\begin{array}{c}\text { Standardized } \\
\text { Coefficients }\end{array}$ & T & Sig. \\
\cline { 2 - 7 } & B & Std. & Beta & & \\
& & Error & & & \\
\hline (Constant) & $-0,620$ & 1,033 & & $-0,600$ & 0,551 \\
CGScore & 0,077 & 0,234 & 0,047 & 0,328 & 0,744 \\
\hline
\end{tabular}

Dependent Variable: Pengungkapan Laporan Keuangan

Sumber: Score CG dan Laporan Tahunan

\subsection{Pembahasan}

\section{Pengaruh Kualitas Corporate Governance} Terhadap Asimetri Informasi

Hasil pengujian pengaruh Kualitas CG terhadap asimetri informasi menunjukkan hasil negatif signifikan sesuai dengan hipoesis, hal ini karena Corporate governance merupakan sebuah konsep yang didasarkan pada teori keagenan, yang diharapkan dapat berfungsi sebagai suatu alat untuk memberikan keyakinan kepada para investor bahwa mereka akan menerima return atas dana yang telah diinvestasikan. Penerapan Corporate governance yang baik memberika keyakinan kepada investor bahwa manajer akan bekerja sesuai dengan harapan principal, manajer tidak akan mencuri atau menggelapkan atau menginvestasikan ke dalam proyek-proyek yang tidak menguntungkan berkaitan dengan dana (capital) yang telah ditanamkannya, dan juga berkaitan dengan bagaimana para investor mengontrol para manajer sehingga memberikan keuntungan bagi para investor. (Nasreddin, 2016)

Corporate governance meliputi prosedur dan pengendalian yang diciptakan untuk menjamin bahwa manajemen bertindak untuk kepentingan pemegang saham, dengan demikian akan mengurangi kemungkinan manajer bertindak untuk kepentingan dirinya sendiri, atau melakukan tindakan yang menyimpang dari tujuan untuk memaksimumkan profit. (Kanagaretnam et all, 2007)

Corporate Governance yang baik diharapkan dapat meningkatkan kinerja perusahaan melalui pengawasan atau monitoring kinerja manajerial serta menjamin terciptanya akuntabilitas manajemen terhadap principal berdasarkan mekanisme yang ada. Konsep corporate governance ini pada intinya menghendaki adanya transparansi yang lebih baik bagi semua pengguna laporan keuangan sehingga pengguna mendapatkan informasi yang memadai yang digunakan sebagai dasar pengambilan keputusan.

Dalam penelitian ini Kualitas CG yang diukur dengan Score CG memudahkan bagi investor, kreditor, atau pengguna informasi yang lain untuk menilai penerapan prinsip-prinsip korporasi yang sehat sebagaimana disyaratkan dalam GCG. Score CG yang tinggi berarti perusahaan telah menerapkan prinsip-prinsip korporasi yang sehat, dengan demikian investor mendapatkan jaminan atas investasinya pada suatu perusahaan sehingga mengurangi asimetri informasi. Asimetri informasi adalah suatu keadaan dimana agent mempunyai informasi yang lebih banyak tentang perusahaan dan prospek dimasa yang akan datang dibandingkan dengan principal. Kondisi ini memberikan kesempatan kepada agent menggunakan informasi yang diketahuinya untuk memanipulasi pelaporan keuangan sebagai usaha untuk memaksimalkan kemakmurannya (Rahmawati, et al, 2006).

Hasil penelitian ini sesuai dengan Ndungo, 2014 yang mendapatkan hasil bahwa corporate governance yang diukur dengan karakteristik corporate governance, yaitu kepemilikan manajerial, independensi anggota dewan, dam dualitas CEO, hasil pengujian menunjukkan kepemilikan manajerial, independensi anggota dewan berpengaruh signifikan negatif terhadap informasi asimetri, sedangkan dualitas CEO berpengaruh positif terhadap asimetri 
informasi sebagaimana yang telah dihipotesiskan. Hasil yang sama juga diperoleh oleh Kanagaretnam (2007) yaitu corporate governance berpengaruh terhadap negatif terhadap asimetri informasi.

\section{Pengaruh Kualitas Corporate Governance Terhadap Asimetri Informasi Melalui Pengungkapan Laporan Keuangan}

Pengujian atas hipotesis kualitas Corporate Governance berpengaruh terhadap Asimetri Informasi Melalui Pengungkapan Laporan Keuangan menunjukkan hasil yang tidak signifikan artinya pengungkapan laporan keuangan bukan merupakan variabel antara dalam pengaruh corporate governance score terhadap asimetri informasi. Dalam penjelasan sebelumnya CG optimal menghendaki perusahaan untuk menyediakan discolsure yang cukup yang tidak hanya meliputi informasi keuangan namun non keuangan yang meliputi visi, misi, sasaran usaha, dan strategi perusahaan, kondisi keuangan, susunan dan kompensasi pengurus, pemegang saham pengendali, kepemilikan saham oleh aggota dewan direksi dan komisaris, sistim manajemen risiko, sistem pengaasan dan pengendalian internal (KNKG, 2006). Corporate governance yang optimal juga akan meningkatkan efektifitas anggota dewan, melalui pengawasan yang baik yang dilakukan oleh dewan komisaris, maka akan meningkatkan kualitas kerja direksi. Hal ini akan meningkatkan kualitas dan kuantitas informasi ternyata tidak terbukti. Beberapa hal yang kemungkinan penyebab kenapa hipotesis tidak terbukti adalah dalam penelitian ini corporate governance diukur dengan menggunakan corporate governance score, yaitu peringkat corporate governance yang dikeluarkan oleh Indonesian Institute for Corporate Governance (IICG) dimana dalam pemberian peringkat didasarkan pada prinsipprinsip OECD yang terdiri dari: a). Hak dan kewajiban pemegang saham (20\%) b). Perlakuan Yang Adil Terhadap Pemegang Saham (15\%) c). Peranan Pemengku Kepentingan dalam Corporate Governance $(15 \%)$ d). Keterbukaan dan transparansi (25\%) e). Tanggug Jawab Dewan (25\%) (Siagian et al, 2007.), dengan demikian pengungkapan laporan keuangan hanya merupakan salah satu faktor penentu dalam peringkat GCG yang mungkin pengaruhnya sangat kecil.

Faktor lain yang bisa dijelaskan mengapa hipotesis 1 tidak terbukti adalah dari data penelitian nampak rata-rata jumlah pengungkapan laporan keuangan relatif sama setiap tahun tapi skor CG perusahaan setiap tahun berubah, hal ini menunjukkan bahwa tekanan pengungkapan laporan keuangan didasarkan pada aturan pengungkapan yang diwajibkan Otoritas Jasa Keuangan (OJK) dari pada keinginan perusahaan dalam memenuhi prinsi-prinsip GCG. Hal ini sasuai dengan yang dinyatakan oleh Siagian, 2007 bahwa pengungkapan laporan keuangan dilakukan karena sifatnya manadatory untuk pemenuhan terhadap standar tidak bertujuan untuk yang lain. Kanagaretnam et al (2007), Chen et al, Conelly et al dalam El Badry et al (2015) mengatakan bahwa mekanisme corporate governance merupakan cara yang tidak langsung dan juga mungkin alat yang tidak sempurna untuk bisa digunakan untuk mengendalikan problema keagenan antara pemegang saham dan manajer sebagai agen perusahaan.

\section{KESIMPULAN}

Penelitian ini menguji pengaruh kualitas corporate governance, terhadap asimetri informasi melalui pengungkapan laporan keuangan. Sampel penelitian adalah perusahaan yang yang terdaftar pada Bursa Efek Indonesia dan terscore nilai GCG oleh CGPI dan termuat di majalah SWA. Analisis data menggunakan regresi linier berganda. Adapun hasil penelitian dapat disimpulkan sebagai berikut: a) Pengujian goodness of fit (Uji kesesuaian model) pada pengaruh langsung antara kualitas CG terhadap asimetri informasi menunjukkan model yang dibangun fit, artinya variabel corporate governance score, mampu menjelaskan variasi perubahan asimetri informasi, b) Pengujian pengaruh kualitas corporate governance terhadap asimetri informasi menunjukkan hasil yang signifikan. Kualitas Corporate governance menjadi pertimbangan dalam keputusan untuk membeli saham sehingga mengurangi asimetri informasi, c) Hasil uji goodness of fit (uji kesesuaian model) pengaruh kualitas CG terhadap asimetri informasi melalui pengungkapan laporan keuangan menunjukkan hasil yang tidak signifikan, hal ini menunjukkan bahwa variable pengungkapan laporan keuangan tidak menjadi variable penjelas hubungan CG terhadap asimetri informasi, d) Hasil uji pengaruh kualitas CG terhadap asimetri informasi melalui pengungkapan laporan keuangan menunjukkan hasil yang tidak signifikan, hal ini berarti pengungkapan laporan keuangan bukan menjadi variable mediasi hubungan GCG terhadap asimetri informasi. Pengungkapan laporan keuangan dilakukan perusahaan karena semata-mata sifatnya mandatory 
Keterbatasan dalam penelitian ini adalah:

a. Sampel penelitian kurang banyak, karena data score CG diambil dari majalah SWA yang terbatas hanya untuk 50 perusahaan yang mempunyai Score CG tertinggi (Most Trusted Company) dari berbagai jenis industry, jangka waktu 6 tahun, dan industry keuangan dikeluarkan dari sampel.

b. Sampel penelitian kurang bervariasi, karena dari hasil seleksi sampel yang terjaring dalam seleksi banyak dari perusahaan BUMN, dimana perusahaan tersebut pemenuhan terhadap aturan GCG cukup baik karena menjadi kewajiban bagi perusahaan untuk memenuhi aturan penerapan good corporate govaernance

c. Data pengungkapan laporan keuangan perusahaan selama periode pengamatan relative sama sehingga variabilitas data kurang, sedangkan score CGnya bervariasi, oleh karena itu hasil penelitian menjadi kurang baik.

Dengan mendasarkan pada keterbatasan penelitian yang sudah dipaparkan di atas, maka saran untuk penelitian selanjutnya adalah:

a. Sebaiknya sampel penelitian diperluas tidak hanya terbatas perusahaan yang terscore oleh IICG yang dimuat di majalah SWA tapi semua perusahaan yang sudah mendapat Score $C G$.

b. Sampel penelitian sebaiknya lebih bervariasi, lebih banyak perusahaan swasta yang penerapan GCG nya karena didasarkan pada kesadaran akan kebutuhan untuk menerapkan tata kelola yang baik, bukan karena pemenuhan terhadap undangundang, sehingga kemungkinan manfaatnya bisa dirasakan.

c. Periode waktu penelitian masih memungkinkan untuk diperpanjang, sehingga mendapatkan sampel yang lebih banyak dengan perusahaan yang lebih bervariasi sehingga hasil penelitian lebih baik.

\section{REFERENSI}

Cormier, D. M.J. Ledoux, M. Magnan, W. Aerts. (2010). Corporate Governance and Information Asymmetry Between Managers and Investor. Emerald Group Publishing Limited. Vol 10.Issue 5. PP574-589.

ELBadry, A. D. Gounopoulos, and F. Skinners (2015). Governance Quality and Information Asymmetry. Financial Market Institution and Instrument. New york University. Salomon Center.
Kanagaretnam. K, G. J. Lobo, dan D. J. Whalen. (2007). Does Good Corporate Governance Reduce Information Asymmetry Around Quarterly Earnings Announcement?. Electronics Journal

Latan, H dan S. Temalagi. (2013). Analisis Multivariate Teknik dan Aplikasi Menggunakan program IBM SPSS 20. CV Alfabeta. Bandung

Komite Nasional Kebijakan Governance. (2006). Pedoman Umum Corporate Governance Indonesia.

Nassreddin. G., (2016). Determinants of financial information disclosure: A visualization test by cognitive mapping technique. Journal of Economics, Finance, and Administrative Science 21. Elseiver.

Ndungo, M. W. (2014). Effect of Corporate Governance on Information Assymetry Between Managers and Investor in Firm Listed at The Nairobi Securitis Exchange school of Business University of Nairobi. Research Project Report. University of Nairobi.

Rahmawati, (2006). Pengaruh Asimetri Informasi Terhadap manajemen Laba Pada perusahaan Perbankan Yang Terdaftar di BEJ. SNA X. Makasar

Riduwan dan Kuncoro, (2017). Cara menggunakan dan Memaknai Path Analysis. Alfabeta. Bandung

Santoso, S. (2012). Analisis SPSS pada Statistik

Parametri. PT. Elex Media Komputindo. Jakarta

Shroff. N., A. Y. Sun, D. Hal, dan W. Zhang. (2013).

Voluntary Disclosure and Information

Asymmetries Evidence from The 2005

Securities Offering Reform. Journal of

Accounting Research. Vol.51. Dec 2013

Siagian, T., F., S. V. Siregar, dan Y. Rahadian. (2007). Corporate Governance, Disclosure Quality, Ownership Structure, and Firm Value. Departemen of Accounting. Faculty of Economics, University of Indonesia

Sugiono. (2011). Metode Penelitian Kuantitatif, Kualitatif, dan R\&D. Alfabeta. Bandung Laporan Tahunan. Simposium Nasional Akuntansi II

Suripto. B. (1999). Pengaruh Karakteristik Perusahaan Terhadap Luas Ungkapan Sukarela.

Wallace, R. S, O. K. Naser, dan A.Mora. (1994). The Relation Between The Comphrehensiveseness of Corporate Annual Report and Firm Characteristic in Spain. Accounting and Business Research 